\title{
Experimental Determination of the Sn-Cu-Ni Phase Diagram for Pb-Free Solder Applications
}

\author{
HECTOR M. HENAO, CHING-SHUN CHU, JUAN P. SOLIS, and KAZUHIRO NOGITA
}

The rapid increase of scrapped electrical products disposed in landfill sites is significantly influencing the environment because of the composition of the associated components. This situation has been the stimulus for the international community to issue a directive to prohibit the use of $\mathrm{Pb}$-containing solders in electronic devices and effectively ban such products on the market. The $\mathrm{Sn}-\mathrm{Cu}-\mathrm{Ni}$ has become increasingly significant as it is used in several solder alloys and more generally both $\mathrm{Cu}$ and $\mathrm{Ni}$ are common substrates that interact with Sn-based solders in microelectronic applications. However, there is currently an insufficient understanding of the phase equilibria and the associated phase diagrams of many Sn alloys. The present work implemented an experimental methodology to obtain high accuracy results for the phase equilibria between one liquid and one or two intermetallic compounds. The $\mathrm{Sn}-\mathrm{Cu}-\mathrm{Ni}$ and the associated $\mathrm{Sn}-\mathrm{Cu}$ and $\mathrm{Sn}-\mathrm{Ni}$ binary systems have been re-evaluated and compared with the literature. The liquidus and the invariant lines were determined for the $\mathrm{Sn}-\mathrm{Cu}-\mathrm{Ni}$ ternary at the temperatures ranges of between $240{ }^{\circ} \mathrm{C}$ and $270{ }^{\circ} \mathrm{C}$. The result will contribute to filling phase equilibria data gaps in the $\mathrm{Sn}$-rich corner of the $\mathrm{Sn}-\mathrm{Cu}-\mathrm{Ni}$ alloy system.

https://doi.org/10.1007/s11663-018-1456-8

(C) The Author(s) 2018

\section{INTRODUCTION}

ON the 1st of July 2006, the European Union issued a directive prohibiting the use of $\mathrm{Pb}$-containing solders in electronic devices and effectively banning such products from the market. Legislators in other jurisdictions, including Japan, China, and USA are considering regulations that would have a similar effect. ${ }^{[1-3]}$ This is the reason that in recent decades, $\mathrm{Pb}$-free solders have seen widespread use in the industry and there has been an increased stimulus for research. This research has included large multi-institution projects to develop thermodynamic databases for solder alloys; in the EU, this has been conducted within the COST project ${ }^{[4]}$ and in the USA this has been led by NIST. ${ }^{[5]}$ These efforts have resulted in the publication of an Atlas of Phase Diagrams for Lead-Free Soldering ${ }^{[6]}$ and been the

HECTOR M. HENAO and JUAN P. SOLIS are with the Metallurgy and Materials Engineering Department, Technical University Federico Santa María, Avenida España, 2340000 Valparaíso, Chile. Contact e-mail: hector.henao@usm.cl CHINGSHUN CHU is with the School of Mechanical and Mining Engineering, The University of Queensland, St. Lucia, QLD 4072, Australia. KAZUHIRO NOGITA is with the Nihon Superior Centre for the Manufacture of Electronic Materials (NS CMEM), School of Mechanical and Mining Engineering, The University of Queensland, St. Lucia, QLD 4072, Australia and also with the School of Mechanical and Mining Engineering, The University of Queensland. Manuscript submitted October 25, 2017.

Article published online December 20, 2018. stimulus for commercial thermodynamic packages offering lead-free soldering databases including Thermo-Calc. (TCSLD2 database) ${ }^{[7]}$ and MTDATA (MTSOLDERS database). ${ }^{[8]}$

The projects mentioned above have been successful with many key ternary and higher order systems, notably $\mathrm{Sn}-\mathrm{Ag}-\mathrm{Cu}$ and $\mathrm{Au}-\mathrm{Ni}-\mathrm{Sn}$, being characterized but, importantly, key systems remain that have not been fully studied which is an impediment to solder alloy design. An important example is the ternary $\mathrm{Sn}-\mathrm{Cu}-\mathrm{Ni}$ system, which while present in the Thermo-Calc. and MTDATA databases, relies on databases that have not been optimized for the full range of temperatures and compositions relevant to the soldering of electronic materials.

\section{A. Literature Review of the Associated $\mathrm{Sn}-\mathrm{Cu}$ and $\mathrm{Sn}-\mathrm{Ni}$ Binary Systems}

The $\mathrm{Sn}-\mathrm{Cu}$ binary system is fundamental of various soldering alloys, such as $\mathrm{Sn}-\mathrm{Cu}-\mathrm{Ag}$, $\mathrm{Sn}-\mathrm{Cu}-\mathrm{Ni}$, and $\mathrm{Sn}-\mathrm{Ni}-\mathrm{Cu}-\mathrm{Ag}$ and $\mathrm{Sn}-\mathrm{Ag}-\mathrm{Co} \cdot{ }^{[9,10]}$ A summary of the reported phase equilibrium for the $\mathrm{Sn}-\mathrm{Cu}$ system between liquid and $\mathrm{Cu}_{6} \mathrm{Sn}_{5}$ is displayed in Figure 1. Harding et al. ${ }^{[11]} \mathrm{Yu}$ et al., ${ }^{[12]}$ Vuorinen et al., ${ }^{[13]}$ and Thermo-Calc ${ }^{[7]}$ are all in reasonable agreement. On the other hand, the experimental results from Hanson et $a l .{ }^{[14]}$ only agree with results near to the eutectic temperature but show a large deviation as temperature is increased. In addition, the experimental result of 
Gourlay et al. ${ }^{[15]}$ (draw in the Figure 1 for concentrations of $\mathrm{Ni}<0.05 \mathrm{wt}$ pct) indicated a large range of variations from 0.7 to $1.5 \mathrm{wt}$ pet of $\mathrm{Cu}$.

There are numerous of $\mathrm{Sn}-\mathrm{Ni}$ phase equilibria data such as that reported by Liu et al., ${ }^{[16]}$ Schmetterer et al. ${ }^{[17]}$ Zemanova et al. ${ }^{[18]}$ Nash et al., ${ }^{[19]}$ Hanson et al., ${ }^{[14]}$ and Gourlay et al. ${ }^{[15,20]}$; Belyakov et al. ${ }^{[21]}$ covered a temperature range from $200{ }^{\circ} \mathrm{C}$ to $300{ }^{\circ} \mathrm{C}$, whereas Hanson et al..$^{[14]}$ covered $200{ }^{\circ} \mathrm{C}$ to $800{ }^{\circ} \mathrm{C}$. A calculated phase diagram was provided by Ghosh ${ }^{[22]}$; however, only a few of them focus on low $\mathrm{Ni}$ concentrations and temperature ranges (e.g., $240{ }^{\circ} \mathrm{C}$ to $270{ }^{\circ} \mathrm{C}$ ) useful for the present study. Figure 2 displays the current available liquid $/ \mathrm{Ni}_{3} \mathrm{Sn}_{4}$ phase equilibrium at the temperatures of interest and the appreciable differences that exists in the literature. In particular, the

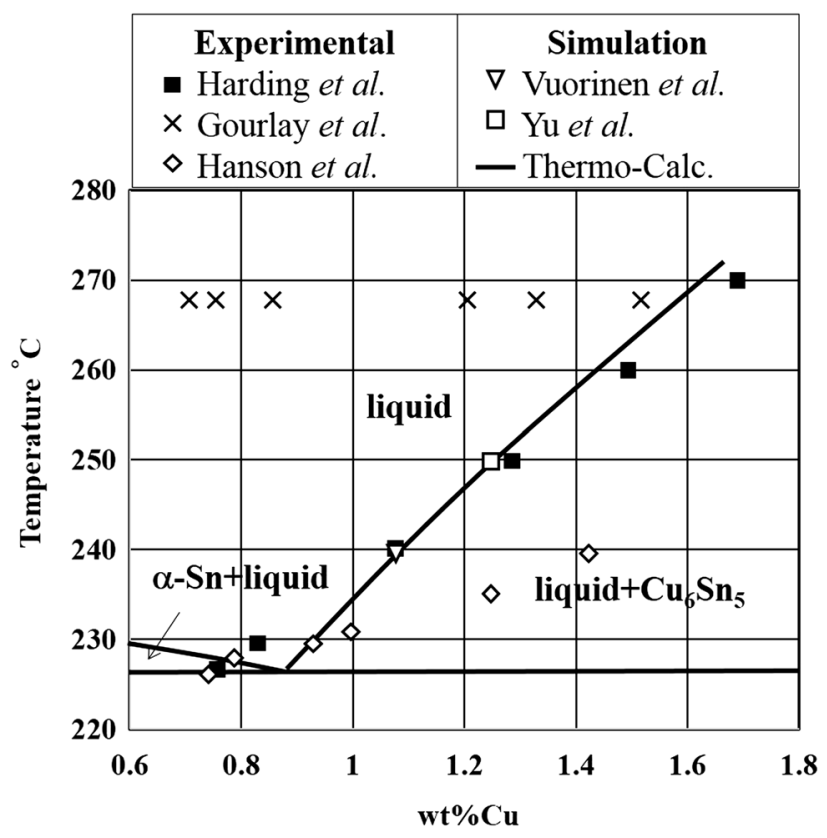

Fig. $1-\mathrm{Sn}-\mathrm{Cu}$ phase diagrams reported in the literature.

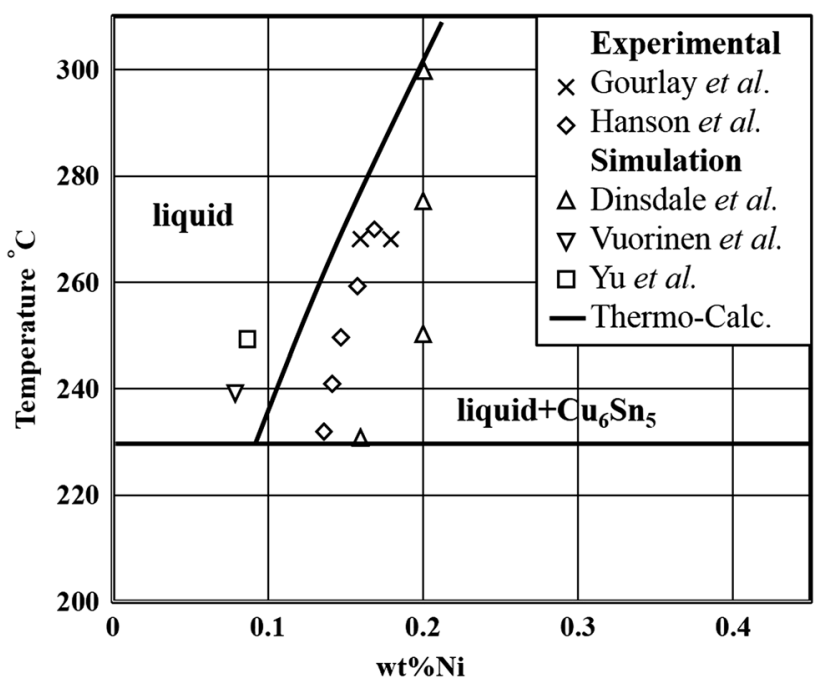

Fig. 2-Sn-Ni phase diagrams reported in the literature. experimental data of Hanson et al. ${ }^{[14]}$ and Gourlay et $a l .{ }^{[15]}$ are quite similar. There are important differences between the experimental works and simulations.

The published information relating to the eutectic points for the $\mathrm{Sn}-\mathrm{Cu}$ and $\mathrm{Sn}-\mathrm{Ni}$ binary systems is summarized in Table I. The ranges of compositions of $\mathrm{Cu}$ and $\mathrm{Ni}$ in the liquid phase in equilibrium with the Inter Metallic Compound (IMC) phases $\mathrm{Cu}_{6} \mathrm{Sn}_{5}$ and $\mathrm{Ni}_{3} \mathrm{Sn}_{4}$ (respectively) are relatively small while the difference of temperatures between eutectic points in the binary systems is $4{ }^{\circ} \mathrm{C}$.

\section{B. Literature Review of the Sn-Cu-Ni Ternary System}

A review of the experimental results reported in the literature for the effect of various elements including $\mathrm{Ni}$, $\mathrm{Au}, \mathrm{Sb}, \mathrm{In}, \mathrm{Co}, \mathrm{Zn}$, and $\mathrm{Bi}$ on the behavior of $\mathrm{Sn}-\mathrm{Cu}$-based solder alloys has recently been published. ${ }^{[9]}$

In the case of the $\mathrm{Sn}-\mathrm{Cu}-\mathrm{Ni}$ system, there are a number of studies at high temperatures $\left(>400{ }^{\circ} \mathrm{C}\right)$; however, as is indicated in Table II, only a few publications provide thermodynamic data in the Sn-rich corner at conditions relevant to the soldering of electronic materials (that is temperatures between $220{ }^{\circ} \mathrm{C}$ and $270{ }^{\circ} \mathrm{C}$ and low concentrations of $\mathrm{Cu}$ and $\mathrm{Ni}){ }^{[12,15,23-25]}$ Furthermore, each of them only covers a small portion of the data required and contain contradictory results with respect to the presence of thermodynamically stable phases and the position of the liquidus and the invariant line. As an example, the study on Snugovsky et al. ${ }^{[24]}$ and Vourinen et al. ${ }^{[13]}$ reported the presence of two quasi-peritectic reactions with a difference between both reactions of less than $1{ }^{\circ} \mathrm{C}$, which related to the presence of a ternary intermetallic compound described as $\mathrm{Cu}_{33} \mathrm{Ni}_{23} \mathrm{Sn}_{44}$. The composition of the supposed ternary phase was assumed based on chemical analysis using electron probe microanalyzer (EPMA); however, the phase was not characterized by $\mathrm{X}$-ray diffraction (XRD). Furthermore, there was no agreement regarding the composition of the ternary phase. A summary of reported liqiudus lines is displayed in Figure 3 including the experimental work reported by Gourlay et $a l^{[15]}$ and simulation reported by Vourinen et $a l^{[13]}$ and $\mathrm{Yu}$ et $a l^{[12]}$ The figure indicates small differences in terms of the position of the liquidus lines even between $240{ }^{\circ} \mathrm{C}$ and $268^{\circ} \mathrm{C}$.

All the experimental works (and simulation) reported a high solubility of $\mathrm{Ni}$ and $\mathrm{Cu}$ in the phases $\mathrm{Cu}_{6} \mathrm{Sn}_{5}$ and $\mathrm{Ni}_{3} \mathrm{Sn}_{4}$, respectively. The solubility for both elements is temperature dependent. For instance, Ni has a solubility between 29 at. pct at $400{ }^{\circ} \mathrm{C}$ to 24 at. pct $\mathrm{Ni}$ at $220{ }^{\circ} \mathrm{C}$ in $(\mathrm{Cu}, \mathrm{Ni})_{6} \mathrm{Sn}_{5} \cdot{ }^{13]}$ The solubility of $\mathrm{Cu}$ in $(\mathrm{Ni}, \mathrm{Cu})_{3} \mathrm{Sn}_{4}$ ranges from 4 at. pet at $700{ }^{\circ} \mathrm{C}$ to 6 at. pct at $220{ }^{\circ} \mathrm{C}$. ${ }^{[26]}$

\section{Critical Review of the Experimental Works Reported in the Literature}

In the opinion of the authors, the discrepancies in the experimental position of the liquidus lines observed in the in Figures 1 through 3 are related mainly to the method of chemical analysis. For experimental works that used wet chemical analysis to determine the 
Table I. Summary of Composition and Temperature of Eutectics in Sn-Cu and Sn-Ni Binary Systems

\begin{tabular}{llccc}
\hline System & \multicolumn{1}{c}{ Authors } & Reference No. & Temperature $\left({ }^{\circ} \mathrm{C}\right)$ & Weight Percent of Cu or Ni \\
\hline Sn-Cu & Harding and Pell Walpole (1948) & 11 & 227 & 0.754 \\
& Thermo-Calc & 7 & 226.8 & 0.885 \\
& Hanson (1934) & 14 & 226.91 & 0.746 \\
Sn-Ni & Nash et al. $(1985)$ & 19 & 231.3 & 0.163 \\
& Hanson et al. $(1934)$ & 14 & 232 & 0.134 \\
& Ghosh (1999) & 22 & 231.1 & 0.167 \\
& Belyakov and Gourlay (2012) & 21 & 231.4 & 0.090 \\
\hline
\end{tabular}

Table II. Literature Summary for Ternary Sn-Cu-Ni System

\begin{tabular}{|c|c|c|c|}
\hline Authors & Method & Results & Remarks \\
\hline Schmetterer et al. (2009) & equilibria/fast quenching/ & isothermal at & not much information about \\
\hline $\mathrm{Sn}-\mathrm{Cu}-\mathrm{Ni}$ & EPMA-XRD & $220^{\circ} \mathrm{C}, 400{ }^{\circ} \mathrm{C}$ & Sn-rich composition \\
\hline Ref. 26 & crucible: vacuumed silica ampoule & $500{ }^{\circ} \mathrm{C}, 700{ }^{\circ} \mathrm{C}$ & $\begin{array}{l}\text { ternary solubilities were } \\
\text { characterized } \\
\text { no indication of achievement of a } \\
\text { glassy phase during quenching }\end{array}$ \\
\hline Lin et al. (2002) & equilibria/fast quenching/ & isothermal at & only one reasonable result for \\
\hline $\mathrm{Sn}-\mathrm{Cu}-\mathrm{Ni}$ & EPMA-XRD & $240{ }^{\circ} \mathrm{C}$ & equilibria $\mathrm{Sn}-\mathrm{Ni}_{3} \mathrm{Sn}_{4}-\mathrm{Cu}_{6} \mathrm{Sn}_{5}$ \\
\hline Ref. 23 & crucible: vacuumed silica ampoule & & $\begin{array}{l}\text { at.pct } \mathrm{Ni}=1.1 \text {, at.pct } \mathrm{Cu}=0.6 \\
\text { no indication of achievement of a } \\
\text { glassy phase during quenching }\end{array}$ \\
\hline Snugovsky et al. (2006) & equilibria/Fast quenching/EPMA & invariant lines & reported of a ternary compound \\
\hline $\mathrm{Sn}-\mathrm{Cu}-\mathrm{Ni}$ & of IMC. & $235^{\circ} \mathrm{C}$ to & $\mathrm{Cu}_{33} \mathrm{Ni}_{23} \mathrm{Sn}_{44}$ \\
\hline Ref. 24 & crucible: $\mathrm{BN}$ (boron nitride) & $227^{\circ} \mathrm{C}$ & $\begin{array}{l}\text { no reported XRD. } \\
\text { no indication of achievement of a } \\
\text { glassy phase during quenching }\end{array}$ \\
\hline Gourlay et al. (2010) & equilibria/fast quenching/EPMA & isothermal at & no indication of achievement of a \\
\hline $\mathrm{Sn}-\mathrm{Cu}-\mathrm{Ni}$ & crucible: stainless-steel cups & $268{ }^{\circ} \mathrm{C}$ & glassy phase during quenching \\
\hline Ref. 15 & $\begin{array}{l}\text { coated with BN. } \\
\text { settling of the IMC on the bottom } \\
\text { of the crucible }\end{array}$ & & \\
\hline $\begin{array}{l}\text { Yu et al. and Vuorinen } \\
\text { et al. (2007) }\end{array}$ & CALPHAD & $\begin{array}{l}\text { isothermal at } \\
\quad T=240{ }^{\circ} \mathrm{C}\end{array}$ & $\begin{array}{l}\text { database constructed based on the } \\
\text { experimental works of Wang }\end{array}$ \\
\hline $\mathrm{Sn}-\mathrm{Cu}-\mathrm{Ni}$ & & and $250^{\circ} \mathrm{C}$ & et al., Lin et al., Oberndorff and \\
\hline Ref. 12 & & & Ho et al. \\
\hline
\end{tabular}

composition of the liquid phase (e.g., Hanson et al.), there was no detailed information regarding the procedure, number of duplicates or standard deviation of the measurements. Furthermore, there was no evidence that the selected sample for analysis was free of primary crystals phases. In addition, the modern experimental technique of Atomic Absorption (A. A) and Inductively Coupled Plasma (I.C.P) are more appropriate to analyze the relatively low concentration of $\mathrm{Cu}$ and $\mathrm{Ni}$ reported in the liquid phase.

On the other hand, the experimental work to obtain liquidus lines for the ternary $\mathrm{Sn}-\mathrm{Cu}-\mathrm{Ni}$ system relied upon the determination of chemical composition of the liquid phase in EPMA analysis as is indicated in Table II. There are two difficulties within the application of this technique for the system. Firstly, the accuracy of the analysis is not satisfactory for the relatively small concentrations of nickel and copper in the liquid phase. And, most importantly the analytical technique is only adequate for homogeneous samples, in this case requiring the formation of a glassy metal during the cooling of the sample.
There was no evidence in the references mentioned in Table II that this condition was fulfilled. Indeed, evidence of non-glassy metals can be clearly observed e.g., in Figure 18 of the paper of work of Lin et al. ${ }^{[23]}$ An example of a large discrepancy in the composition of the liquid phase is also observed in the work of Lin at temperature of $240{ }^{\circ} \mathrm{C}$, with values of 0.6 and $1.1 \mathrm{wt}$ pct for copper and $\mathrm{Ni}$, respectively. It is also appreciable in Figures 1 and 3, where there is a large variation in composition within the experimental data reported by Gourlay et $a^{[15]}$ in the binaries and ternary systems.

\section{Experimental Methodologies for Equilibrium Studies of $\mathrm{Sn}-\mathrm{Cu}-\mathrm{Ni}$ Alloy}

The experimental methodologies used in the experimental works reported in the literature are indicated in Table II. In general, this corresponded to the equilibria of samples in silica ampoules or graphite, held isothermally then quenched in cold water. ${ }^{[23,24,26]}$ The samples were analyzed with XRD and the reported compositions 


\title{
Experimental
}

\author{
……... $268^{\circ} \mathrm{C}$, Gourlay et al. \\ ㅁ $\quad 240{ }^{\circ} \mathrm{C}$, Lin et al.
}

Simulation $\quad$ Sn

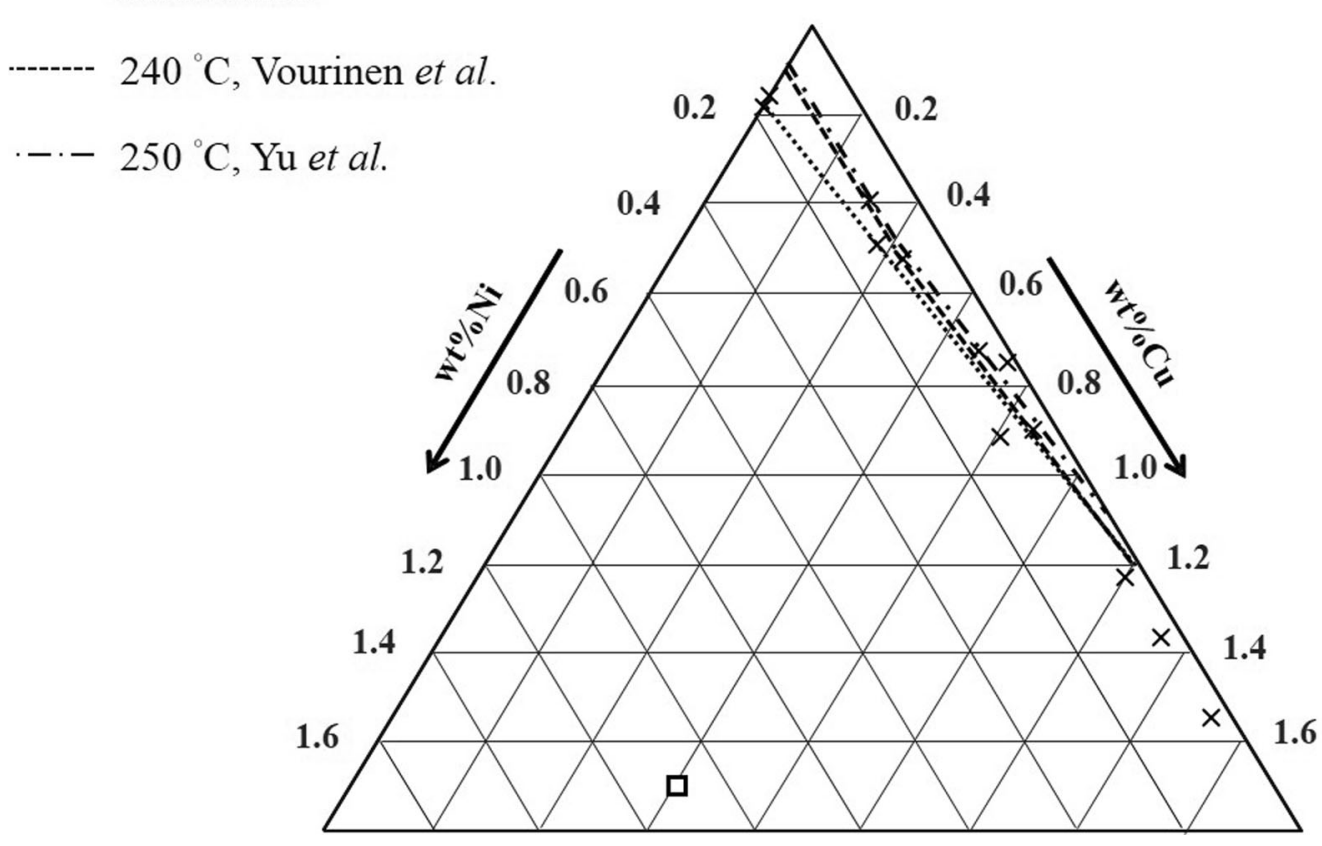

Fig. 3-Isoterms the $\mathrm{Sn}-\mathrm{Cu}-\mathrm{Ni}$ system reported in the literature.

of solid and quenched liquid with EPMA. On the report of the invariant line, the technique used was based on the path of solidification close to equilibrium conditions. The methodology of EPMA analysis for the liquid phase required the formation of a glassy (amorphous) metallic material which is difficult to obtain by quenching in a liquid and there is no evidence in the published paper that the condition was achieved.

An alternative experimental approach to obtain equilibrium information is based on the differences of densities between the liquid and the IMC, ${ }^{[15,16]}$ allowing settling of the IMC on the bottom of the crucible. Then, Scanning Electron Microscopy (SEM) with energy-dispersive X-ray spectroscopy (EDX) can be used to identify the IMC composition while the liquid phases compositions can be determined by Inductively Coupled Plasma-Atomic Emission Spectrometry (ICP-AES) or titration chemical analysis.

\section{E. Objective of the Present Work}

The present work was a starting point to address the incomplete and contradictory information of equilibrium data on the $\mathrm{Sn}-\mathrm{Cu}-\mathrm{Ni}$ alloy and establish an experimental protocol for a modified equilibria/
quenching/Electron Probe Microscopy Analysis (EPMA)-Inductively Coupled Plasma (ICP-AES) analysis methodology. The aim of this project includes

- To identify the underlying reasons for the disparity in the existing results in the literature.

- To design a new experimental approach using state of the art phase equilibrium methodologies and analytical chemical analysis procedures.

- To generate a new Sn-Cu-Ni phase diagram based on reliable experimental data including four liquidus lines at $240{ }^{\circ} \mathrm{C}, 250{ }^{\circ} \mathrm{C}, 260{ }^{\circ} \mathrm{C}$, and $270{ }^{\circ} \mathrm{C}$.

- Characterize the invariant (or invariants) line for the equilibrium between a liquid phase with two IMCs

\section{CORROBORATION OF ATTAINMENT OF HOMOGENEOUS LIQUID DURING FAST QUENCHING}

As indicated in Table II, most of the reported experiments relate to equilibrium of the $\mathrm{Sn}-\mathrm{Cu}-\mathrm{Ni}$ alloy obtained by fast quenching to form aglassy liquid phase. The present work explored the possibility of obtaining that glassy material. For that purpose, a Sn-0.5 wt pet 

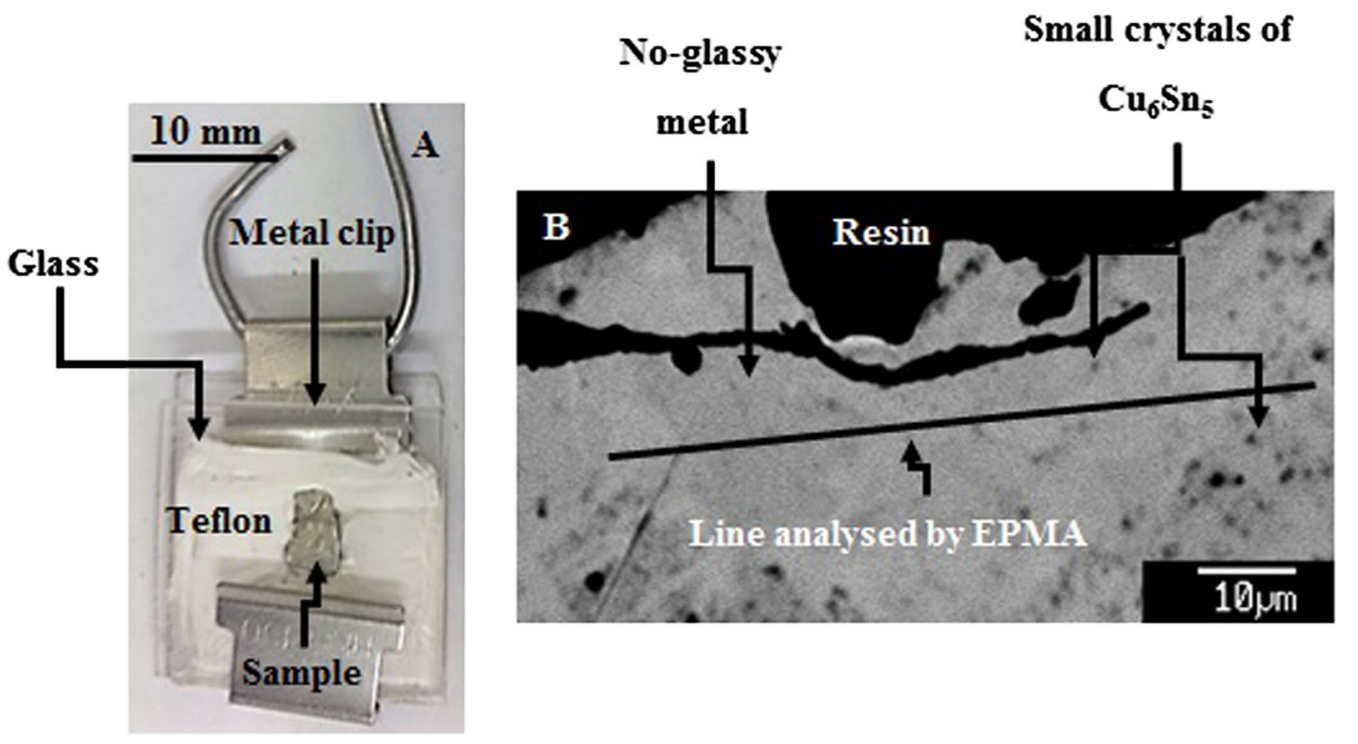

Fig. 4-Experiments of fast quenching/EPMA analysis of liquid phase. (a) Sample between two thin slides of quartz, (b) SEM image of quenched sample.

Table III. Targets for Experimental Methodology

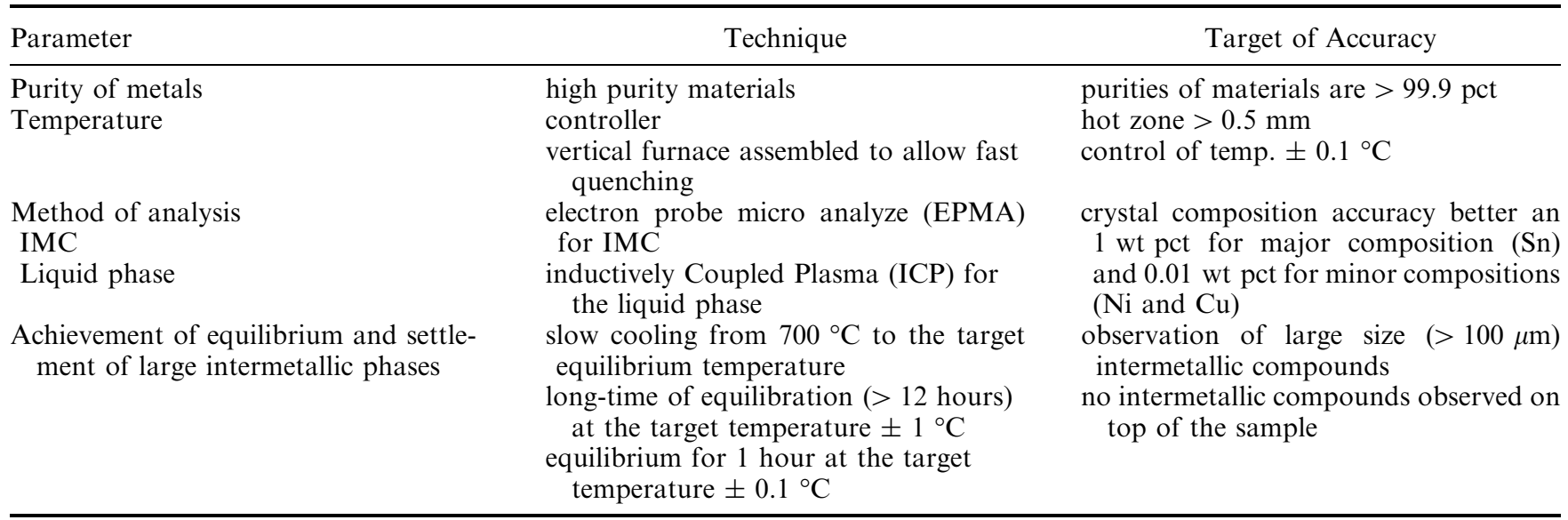

Cu sample with dimensions $10 \mathrm{~mm} \times 10 \mathrm{~mm} \times 0.1 \mathrm{~mm}$ was set between two thin slides of quartz $(0.2 \mathrm{~mm}$ thickness) fixed at a $0.1-\mathrm{mm}$ aperture as shown in Figure 4(a). The sample was heated up to $250{ }^{\circ} \mathrm{C}$ for twenty hours and then was dropped directly into iced water. As indicated in Figure 4(b), even the most effectively quenched area in the sample was heterogeneous with clearly observable small crystal precipitates. EPMA point analysis of the indicated line at a distance between points of $2 \mu \mathrm{m}$ indicated a standard deviation on the concentration of copper larger than the starting concentration of $0.5 \mathrm{wt}$ pet $\mathrm{Cu}$. Given the impossibility of obtaining a glassy material for a simple quenching technique, we ruled out this methodology and developed the experimental procedure described in the following section.

\section{EXPERIMENTAL PROCEDURE}

The experimental methodology adopted in the present work is based on the difference of densities between IMCs and the liquid phase. The densities of $\mathrm{Cu}_{6} \mathrm{Sn}_{5}$ and $\mathrm{Ni}_{3} \mathrm{Sn}_{4}{ }^{[27]}$ are 8.1 and $8.64 \mathrm{~g} / \mathrm{cm}^{3}$, respectively. The density of the liquid close to the eutectic point is $7.31 \mathrm{~g} /$ $\mathrm{cm}^{3}$ (Thermo-calc. calculation). Thus, it can be expected that a clear physical separation by sedimentation of the IMC will occur during liquid/IMC equilibration. Based on these considerations, the experiments were designed to:

- Produce a few large crystals by selection of initial composition to allow an easy physical separation between crystals and the liquid phase. 


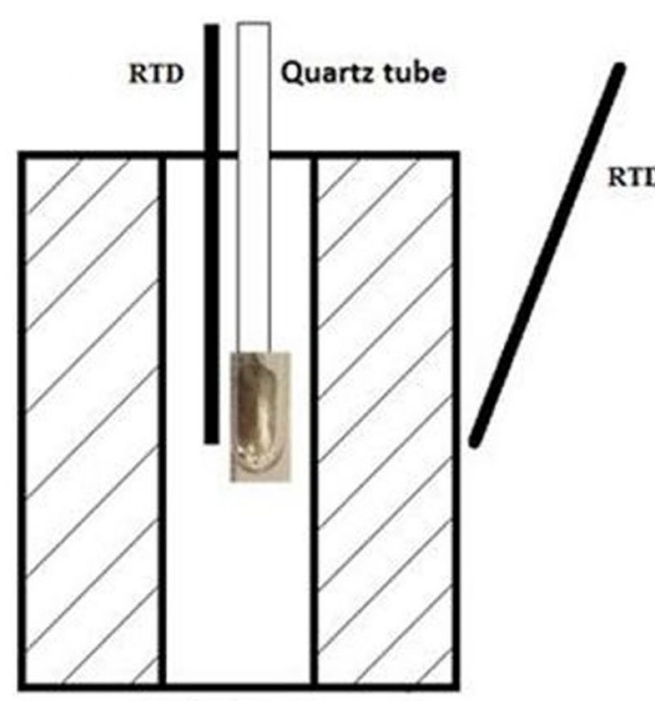

Tube Furnace

(a)

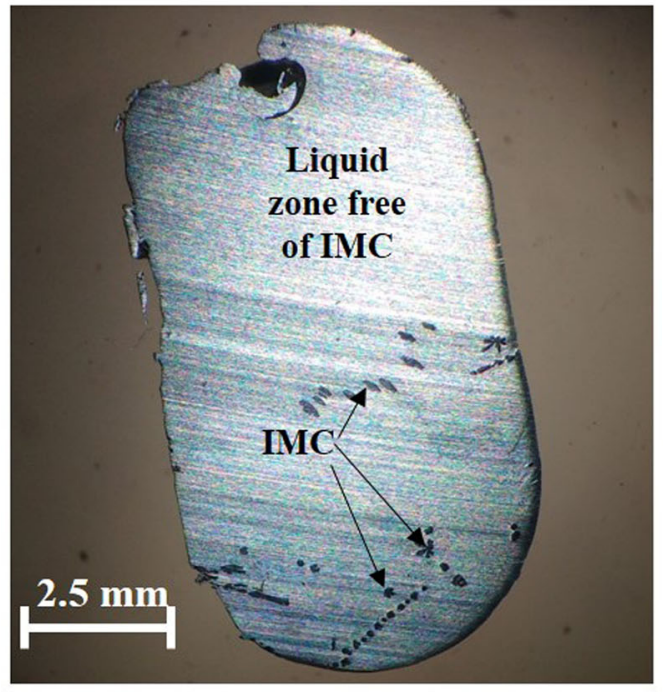

(c)

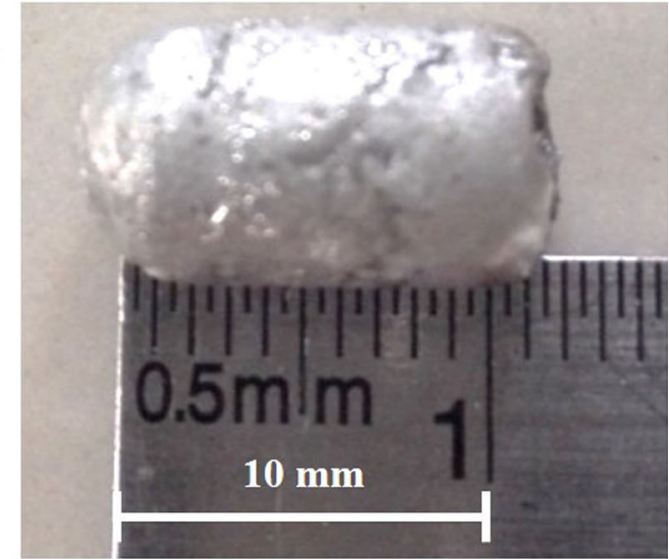

(b)

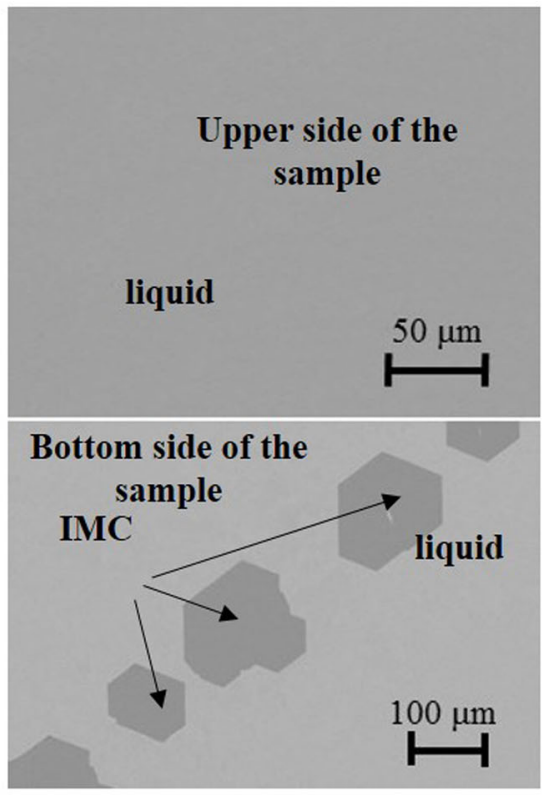

(d)

Fig. 5-Schematic representation of furnace and images of a sample. (a) Schematic representation of furnace, $(b)$ a typical quenched sample, $(c)$ SEM image of a section of the sample, (d) SEM images of upper and bottom side of a section of the sample.

- Promote relatively fast quenching to distinguish the primary phase from what would appear during quenching.

- Ensure the sample is large enough to easily manipulate and to obtain between 0.1 and $0.2 \mathrm{~g}$ for the ICP-AES analysis. The target parameters and verification of the experimental procedure and a summary of parameters used during the experimental work are indicated in Table III. The starting material included 99.99985 pct purity Sn chips, $99.98 \mathrm{wt}$ pct purity $\mathrm{Ni}$ chips, $99.99 \mathrm{wt}$ pct purity $\mathrm{Cu}$ chips (provided by the sponsor of the present work). The electric resistance furnace, schematically described in Figure 5, consist of 6-mm-diameter quartz tubes, an input controller with two Resistance Temperature Detectors (RTD) 3200 series and a power input controller Modal 3216. The electronic scale has an accuracy of 4 decimal digits. 
The RTDs were also calibrated in accordance with the National Australian Testing Association (NATA) standard. The accuracy of control of temperature was tested at the melting point of Sn. Samples of high purity (99.99985 pct) Sn chips were placed into the quartz tubes and sealed under vacuum. The sealed quartz tube was then placed into the tube furnace and positioned at the same level as the tip of the RTD in the hot zone. The sample was heated $\sim 0.54{ }^{\circ} \mathrm{C}$ above the melting point (reported for Kahlbaum as $231.92{ }^{\circ} \mathrm{C}^{[28]}$ ) and a clear liquid phase was observed. Conversely, the sample at $231.39{ }^{\circ} \mathrm{C}$ was solid. Assuming that the activation energy of melting of $\mathrm{Sn}$ does not affect the outcome, this experiment indicated that the temperature can be controlled at a level better than $\pm 0.55^{\circ} \mathrm{C}$.

Table IV. ICP Analysis of Selected Samples

\begin{tabular}{lcccc}
\hline \multicolumn{2}{c}{$\mathrm{Cu}$ (Weight Percent) } & & \multicolumn{2}{c}{ Ni (Weight Percent) } \\
\cline { 1 - 1 } Initial & ICP Analysis & & Initial & ICP Analysis \\
\hline 0.44 & 0.36 & & 0.08 & 0.07 \\
0.48 & 0.40 & & 0.10 & 0.09 \\
0.50 & 0.52 & & 0.12 & 0.11 \\
0.55 & 0.53 & & 0.15 & 0.14 \\
0.80 & 0.78 & & 0.00 & 0.00 \\
0.00 & 0.001 & & 0.00 & 0.00 \\
1.80 & 1.83 & & 0.00 & 0.00 \\
0.00 & 0.001 & & 1.00 & 1.02 \\
\hline
\end{tabular}

$\mathrm{Cu}$ and $\mathrm{Ni}$ were enveloped in a foil of $\mathrm{Sn}$ and placed in the bottom of a silica crucible and on top of the envelope; high purity $\mathrm{Sn}$ was added. The initial compositions were targeted to obtain a low proportion of IMC phases. The samples were positioned in the hot zone and

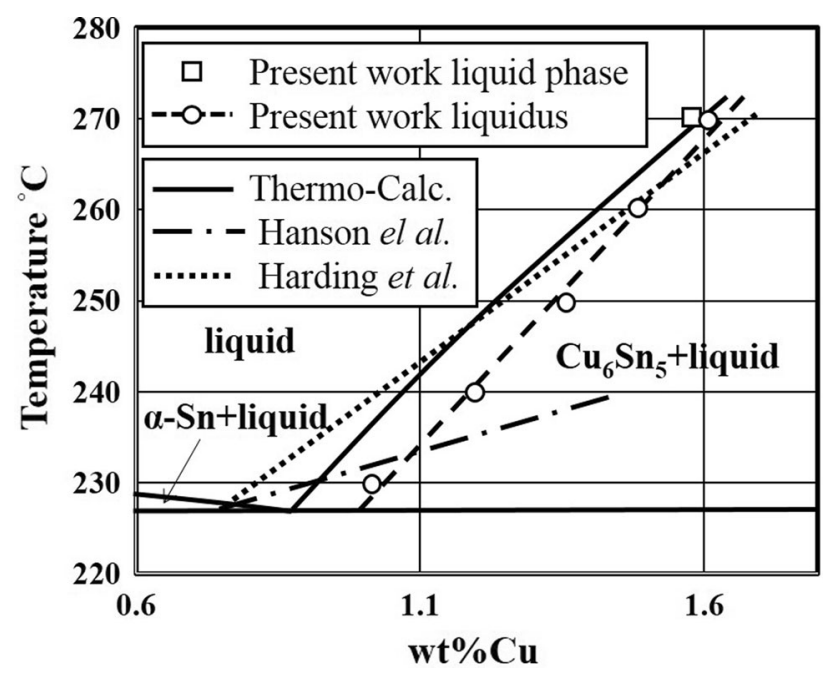

Fig. 6- Section of the Sn-Cu binary system including the present experimental points and the proposed liquidus line for the equilibrium $\mathrm{Cu}_{6} \mathrm{Sn}_{5}$; the figure includes the liquidus lines of Thermo-Calc. simulation and that proposed by Harding et al.

Table V. Composition for Liquid and IMC Phases for the Sn-Cu Binary System

\begin{tabular}{|c|c|c|c|c|c|c|}
\hline \multirow[b]{2}{*}{ No. } & \multirow[b]{2}{*}{ Tem. ${ }^{\circ} \mathrm{C}$} & \multirow{2}{*}{ Initial (Weight Percent) } & \multirow{2}{*}{$\begin{array}{l}\text { Liquid (Weight Percent) } \\
\mathrm{Cu}\end{array}$} & \multicolumn{3}{|c|}{ IMC (Normalized Weight Percent) } \\
\hline & & & & $\mathrm{Sn}$ & $\mathrm{Cu}$ & IMC \\
\hline 1 & 230 & 1.4 & 1.02 & 61.7 & 38.3 & $\mathrm{Cu}_{6} \mathrm{Sn}_{5}$ \\
\hline 2 & 240 & 1.8 & 1.20 & 60.1 & 39.9 & $\mathrm{Cu}_{6} \mathrm{Sn}_{5}$ \\
\hline 3 & 250 & 1.8 & 1.36 & 60.6 & 39.4 & $\mathrm{Cu}_{6} \mathrm{Sn}_{5}$ \\
\hline 4 & 260 & 1.8 & 1.48 & 59.8 & 40.2 & $\mathrm{Cu}_{6} \mathrm{Sn}_{5}$ \\
\hline 5 & 270 & 1.8 & 1.61 & 62.7 & 37.3 & $\mathrm{Cu}_{6} \mathrm{Sn}_{5}$ \\
\hline $6^{*}$ & 270 & 1.6 & 1.58 & $\mathrm{n} / \mathrm{a}$ & $\mathrm{n} / \mathrm{a}$ & $\mathrm{n} / \mathrm{a}$ \\
\hline
\end{tabular}

Table VI. Composition for Liquid and IMC Phases for the Sn-Ni Binary System

\begin{tabular}{|c|c|c|c|c|c|c|}
\hline \multirow[b]{2}{*}{ No. } & \multirow[b]{2}{*}{ Tem. ${ }^{\circ} \mathrm{C}$} & \multirow{2}{*}{$\begin{array}{l}\text { Initial (Weight Percent) } \\
\text { Ni }\end{array}$} & \multirow{2}{*}{$\begin{array}{c}\text { Liquid (Weight Percent) } \\
\mathrm{Ni}\end{array}$} & \multicolumn{3}{|c|}{ IMC (Normalized Weight Percent) } \\
\hline & & & & $\mathrm{Sn}$ & $\mathrm{Ni}$ & IMC \\
\hline 7 & 240 & 0.25 & 0.16 & 72.8 & 27.2 & $\mathrm{Ni}_{3} \mathrm{Sn}_{4}$ \\
\hline 8 & 250 & 0.25 & 0.17 & 74.5 & 25.5 & $\mathrm{Ni}_{3} \mathrm{Sn}_{4}$ \\
\hline $9^{*}$ & 250 & 0.15 & 0.16 & $\mathrm{n} / \mathrm{a}$ & $\mathrm{n} / \mathrm{a}$ & $\mathrm{n} / \mathrm{a}$ \\
\hline 10 & 260 & 0.25 & 0.19 & 73.9 & 26.1 & $\mathrm{Ni}_{3} \mathrm{Sn}_{4}$ \\
\hline $11^{*}$ & 260 & 0.15 & 0.16 & $\mathrm{n} / \mathrm{a}$ & $\mathrm{n} / \mathrm{a}$ & $\mathrm{n} / \mathrm{a}$ \\
\hline 12 & 270 & 0.5 & 0.2 & 72.8 & 27.2 & $\mathrm{Ni}_{3} \mathrm{Sn}_{4}$ \\
\hline $13^{*}$ & 270 & 0.15 & 0.16 & $\mathrm{n} / \mathrm{a}$ & $\mathrm{n} / \mathrm{a}$ & $\mathrm{n} / \mathrm{a}$ \\
\hline 14 & 280 & 0.3 & 0.22 & 74.2 & 25.8 & $\mathrm{Ni}_{3} \mathrm{Sn}_{4}$ \\
\hline
\end{tabular}

$\mathrm{n} / \mathrm{a}$, not applicable because only the liquid phase was observed.

*Only the liquid phase was observed. 


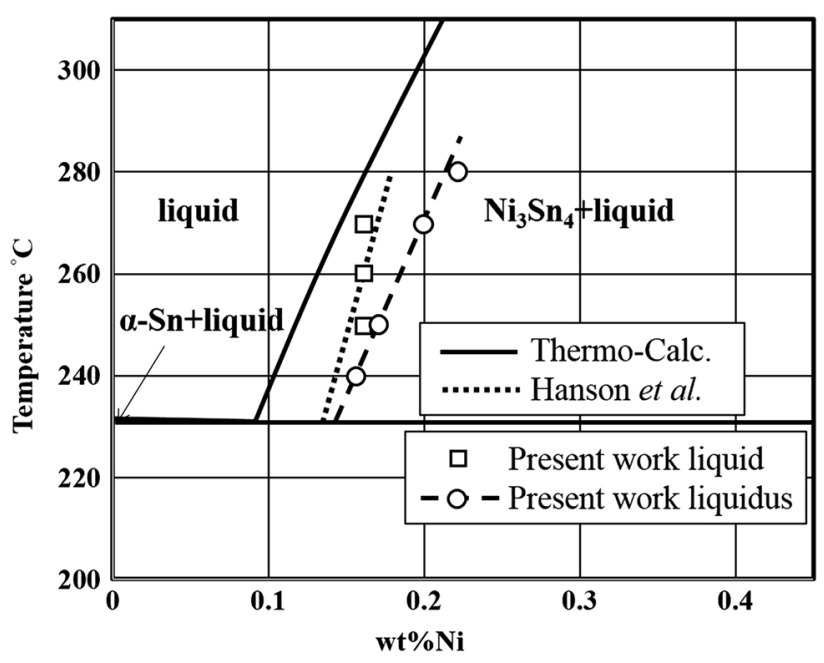

Fig. 7-Section of the Sn-Ni binary system including the present experimental points and the proposed liquidus line for the equilibrium $\mathrm{Cu}_{6} \mathrm{Sn}_{5}$; the figure includes the liquidus lines of Thermo-Calc. simulation and that proposed by Hanrson et al. the temperature in the tube furnace was slowly increased until it approached a preheating temperature of $700{ }^{\circ} \mathrm{C}$. The preheat temperatures were maintained for at least 10 hours before slowly reducing the temperature at a rate of approximately $-2.5 \times 10^{-3}{ }^{\circ} \mathrm{C} / \mathrm{s}$ until the target temperature was reached with an accuracy of $\pm 2^{\circ} \mathrm{C}$. The sample was left at the desired temperature for another 12 hours and finally was held for an one hour at the target temperature with an accuracy of $\pm 0.1^{\circ} \mathrm{C}$. The samples were then fast quenched in water. One-half of the samples were polished for microscopic observation and EPMA analysis of the IMC(s), while the other half of the sample was cut transversely into two sections and the top (and in selected instances the bottom) sections were analyzed by ICP-AES. Figure 5 includes a typical sample obtained after quenching and the respective microscopy image of the top and bottom sides.

The elemental analysis of the IMC was undertaken using a JEOL JXA 8200L (trademark of Japan Electron Optics Ltd., Tokyo) electron probe X-ray microanalyzer (EPMA) with wavelength dispersive detectors (WDD). In the setup

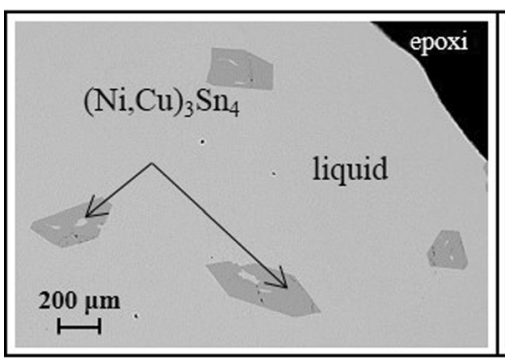

(a)

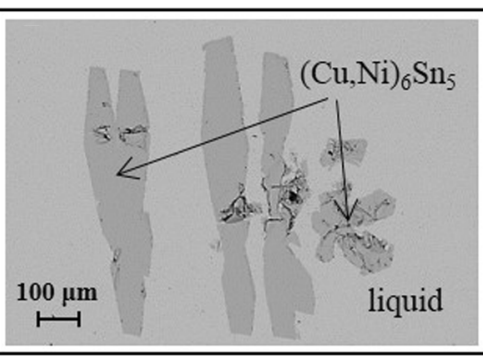

(b)

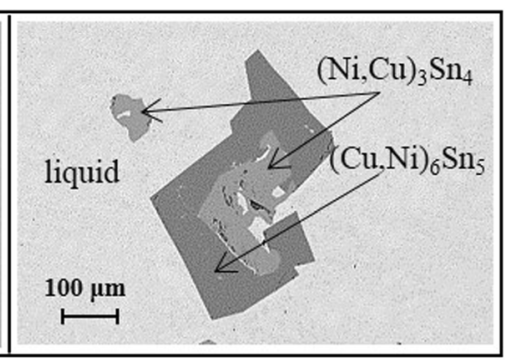

(c)

Fig. 8-SEM images of samples. (a) SEM image of the equilibrium liquid/(Ni,Cu $)_{3} \mathrm{Sn}_{4},(b) \mathrm{SEM}$ image of the equilibrium liquid/(Cu,Ni) $)_{6} \mathrm{Sn}_{5},(c)$ SEM image of the equilibrium liquid//(Ni,Cu) ${ }_{3} \mathrm{Sn}_{4} /\left(\mathrm{Cu}, \mathrm{Ni}_{6} \mathrm{Sn}_{5}\right.$.

Table VII. Composition for Liquid and IMC Phases for the Sn-Cu-Ni Ternary System

\begin{tabular}{|c|c|c|c|c|c|c|c|c|c|}
\hline \multirow[b]{2}{*}{ No. } & \multirow[b]{2}{*}{ Tem ${ }^{\circ} \mathrm{C}$} & \multicolumn{2}{|c|}{ Initial (Weight Percent) } & \multicolumn{2}{|c|}{ Liquid (Weight Percent) } & \multicolumn{3}{|c|}{ IMC (Normalized Weight Percent) } & \multirow[b]{2}{*}{ IMC } \\
\hline & & $\mathrm{Cu}$ & $\mathrm{Ni}$ & $\mathrm{Cu}$ & $\mathrm{Ni}$ & $\mathrm{Sn}$ & $\mathrm{Cu}$ & $\mathrm{Ni}$ & \\
\hline 15 & 240 & 0.6 & 0.4 & 0.32 & 0.17 & $\begin{array}{l}73.82 \\
62.47\end{array}$ & $\begin{array}{l}4.77 \\
23.3\end{array}$ & $\begin{array}{l}21.4 \\
14.2\end{array}$ & $\begin{array}{l}(\mathrm{Ni}, \mathrm{Cu})_{3} \mathrm{Sn}_{4} \\
(\mathrm{Cu}, \mathrm{Ni})_{6} \mathrm{Sn}_{5}\end{array}$ \\
\hline $16^{*}$ & 240 & 0.44 & 0.08 & 0.36 & 0.074 & $\mathrm{n} / \mathrm{a}$ & $\mathrm{n} / \mathrm{a}$ & $\mathrm{n} / \mathrm{a}$ & $\mathrm{n} / \mathrm{a}$ \\
\hline 17 & 250 & 0.4 & 0.4 & 0.33 & 0.18 & 73.42 & 4.39 & 22.2 & $(\mathrm{Ni}, \mathrm{Cu})_{3} \mathrm{Sn}_{4}$ \\
\hline $18 *$ & 250 & 0.48 & 0.1 & 0.4 & 0.09 & $\mathrm{n} / \mathrm{a}$ & $\mathrm{n} / \mathrm{a}$ & $\mathrm{n} / \mathrm{a}$ & $\mathrm{n} / \mathrm{a}$ \\
\hline $19 *$ & 250 & 0.5 & 0.12 & 0.52 & 0.11 & $\mathrm{n} / \mathrm{a}$ & $\mathrm{n} / \mathrm{a}$ & $\mathrm{n} / \mathrm{a}$ & $\mathrm{n} / \mathrm{a}$ \\
\hline 20 & 260 & 1.4 & 0.8 & 0.83 & 0.28 & 61.6 & 20.7 & 17.7 & $(\mathrm{Cu}, \mathrm{Ni})_{6} \mathrm{Sn}_{5}$ \\
\hline 21 & 260 & 1.2 & 0.2 & 1.07 & 0.13 & 73 & 2.1 & 24.9 & $(\mathrm{Ni}, \mathrm{Cu})_{3} \mathrm{Sn}_{4}$ \\
\hline 22 & 260 & 0.4 & 0.5 & 0.42 & 0.26 & 73.74 & 3.48 & 22.8 & $(\mathrm{Ni}, \mathrm{Cu})_{3} \mathrm{Sn}_{4}$ \\
\hline \multirow[t]{2}{*}{23} & 260 & 0.7 & 0.6 & 0.47 & 0.28 & 73.98 & 3.77 & 22.3 & $(\mathrm{Ni}, \mathrm{Cu})_{3} \mathrm{Sn}_{4}$ \\
\hline & & & & & & 63.06 & 22.2 & 14.7 & $(\mathrm{Cu}, \mathrm{Ni})_{6} \mathrm{Sn}_{5}$ \\
\hline 24 & 260 & 1 & 0.2 & 0.85 & 0.16 & 62.92 & 25.6 & 11.5 & $(\mathrm{Cu}, \mathrm{Ni})_{6} \mathrm{Sn}_{5}$ \\
\hline 25 & 260 & 1.1 & 0.4 & 0.47 & 0.3 & 74.01 & 3.79 & 22.2 & $(\mathrm{Ni}, \mathrm{Cu})_{3} \mathrm{Sn}_{4}$ \\
\hline 26 & 270 & 1.2 & 0.2 & 1.07 & 0.14 & 61.93 & 25.68 & 12.4 & $(\mathrm{Cu}, \mathrm{Ni})_{6} \mathrm{Sn}_{5}$ \\
\hline 27 & 270 & 1 & 0.3 & 0.96 & 0.19 & 62.74 & 22.26 & 15.0 & $(\mathrm{Cu}, \mathrm{Ni})_{6} \mathrm{Sn}_{5}$ \\
\hline 28 & 270 & 0.4 & 0.5 & 0.4 & 0.3 & 73.05 & 2.3 & 24.7 & $(\mathrm{Ni}, \mathrm{Cu})_{3} \mathrm{Sn}_{4}$ \\
\hline \multirow[t]{2}{*}{29} & 270 & 0.7 & 0.6 & 0.5 & 0.31 & 74.14 & 3.36 & 22.5 & $(\mathrm{Ni}, \mathrm{Cu})_{3} \mathrm{Sn}_{4}$ \\
\hline & & & & & & 62.79 & 22.08 & 15.3 & $(\mathrm{Cu}, \mathrm{Ni})_{6} \mathrm{Sn}_{5}$ \\
\hline $30 *$ & 270 & 0.55 & 0.15 & 0.53 & 0.14 & $\mathrm{n} / \mathrm{a}$ & $\mathrm{n} / \mathrm{a}$ & $\mathrm{n} / \mathrm{a}$ & $\mathrm{n} / \mathrm{a}$ \\
\hline
\end{tabular}

$\mathrm{n} / \mathrm{a}$, not applicable because only the liquid phase was observed.

*Only the liquid phase was observed. 


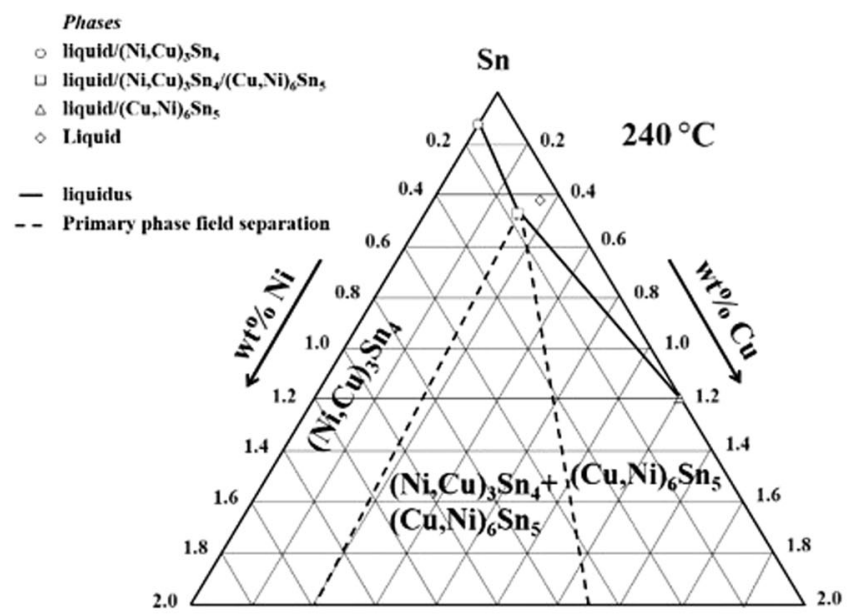

(a)


\section{Phase equilibrium}

○ liquid/(Ni,Cu) $)_{3} \mathrm{Sn}_{4}$

$\square \operatorname{liquid} /(\mathrm{Ni}, \mathrm{Cu})_{3} \mathrm{Sn}_{4} /(\mathrm{Cu}, \mathrm{Ni})_{6} \mathrm{Sn}_{5}$

$\triangle \operatorname{liquid} /(\mathbf{C u}, \mathbf{N i})_{6} \mathrm{Sn}_{5}$

$\diamond$ liquid



$\mathrm{Ni}, \mathrm{Cu})_{3} \mathrm{Sn}_{4}$

- Liquidus $\longrightarrow$ Liquidus

- - - - Primary phase field separation

(c)

Fig. 9-Experimental points for the equilibrium liquid/IMCs. (a) Experimental points at $240{ }^{\circ} \mathrm{C}$, (b) experimental points at $250{ }^{\circ} \mathrm{C}$, (c) experimental points at $260{ }^{\circ} \mathrm{C},(d)$ experimental points at $270{ }^{\circ} \mathrm{C}$.

of the EPMA device, an acceleration voltage of $15 \mathrm{kV}$ and a probe current of $15 \mathrm{nA}$ were used. The Duncumb-Philibert ZAF correction procedure supplied with the JEOL JXA 8200L probe was also applied. Standards of $\mathrm{Cu}_{6} \mathrm{Sn}_{5}$ were prepared for high-purity metals, and $\mathrm{Ni}$ (Charles $\mathrm{M}$.
Taylor, Stanford, CA) was used in the EPMA measurements. Eight points were analyzed in each sample; the standard deviation of measured compositions of the standards and samples indicated an accuracy of the elemental analysis of $\pm 0.2 \mathrm{wt}$ pct. 


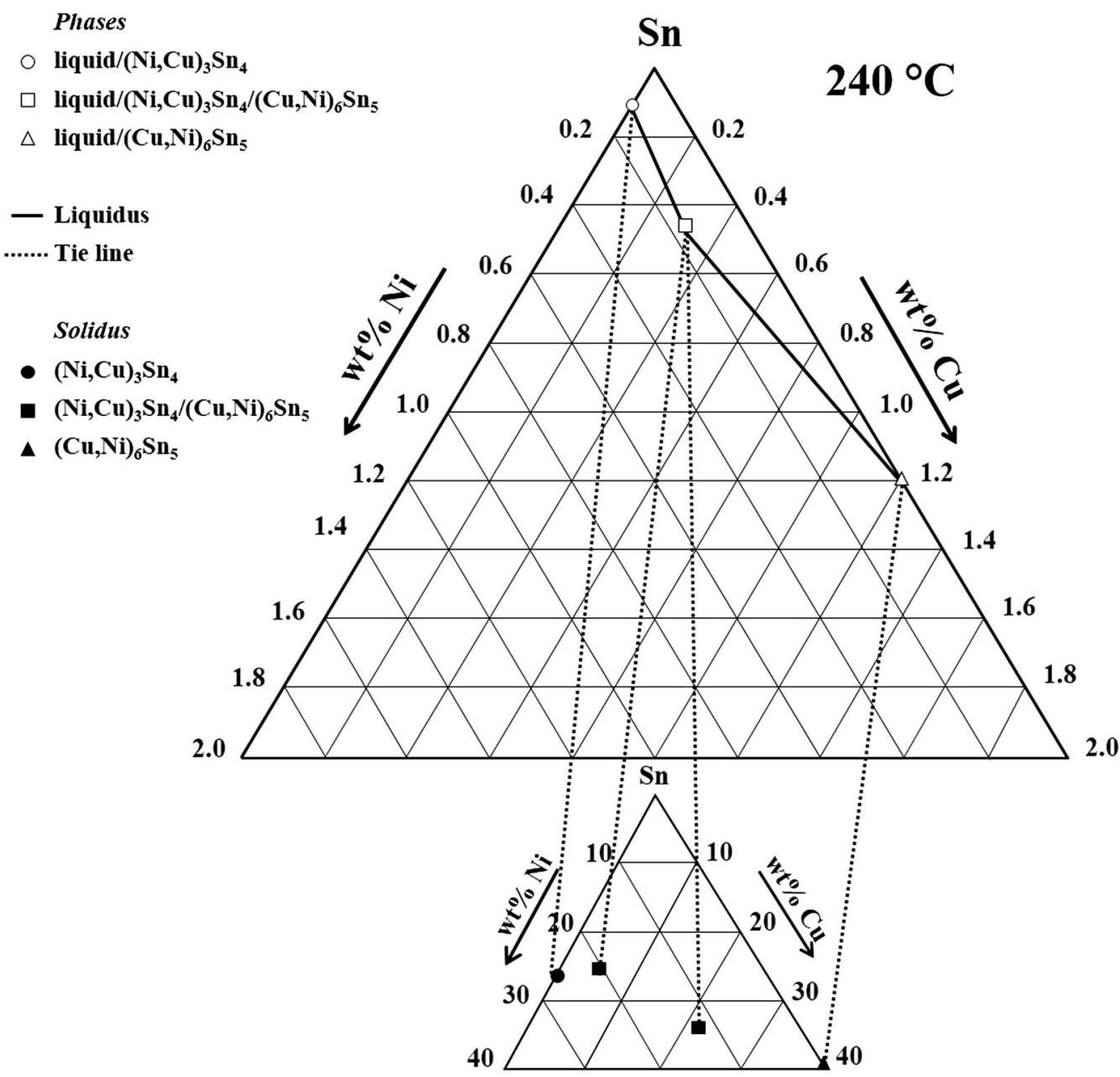

Fig. 10-Equilibrium liquid/IMCs at $250{ }^{\circ} \mathrm{C}$.

It was confirmed using microscopy that the top of the samples were liquid before quenching. In order to analyze the sample by triplicate, the liquid phase (top of the samples) was cut in three pieces each one with a weight of approximate $0.1 \mathrm{~g}$. The samples were dissolved in "aqua regia," diluted with water in a volumetric of $25 \mathrm{~mL}$ and analyzed using ICP-AES. To corroborate the accuracy of results, a number of samples of selected composition to assure the formation of liquid phases (without intermetallic compounds) were melted at $400{ }^{\circ} \mathrm{C}$, fast quenched and analyzed by ICP-AES. The results shows in Table IV indicate that the accuracy of the analysis is of the order of 0.05 wt pet for $\mathrm{Cu}$ and $0.01 \mathrm{wt}$ pet for $\mathrm{Ni}$. Furthermore, the triplicate analysis of the liquid phases in equilibrium with IMC indicated standard deviations of the order of 0.05 for experiments in the binary $\mathrm{Sn}-\mathrm{Cu}$ and 0.01 for the experiments in the binary $\mathrm{Sn}-\mathrm{Ni}$.

\section{EXPERIMENTAL RESULTS AND DISCUSSION}

A total of 30 experiments will be reported which fulfil the selection criteria based on the following observations:

- A low proportion of IMCs in the sample

- Good sedimentation with the IMCs of large size ( $>100 \mu \mathrm{m})$ accumulating in the bottom of the sample

- A large liquid area in the upper side of the sample free of IMCs. The experimental results for the $\mathrm{Sn}-\mathrm{Cu}$ and Sn-Ni binaries are summarized in Tables V and VI, respectively. The tables include the initial composition, the equilibrium composition of liquid and the composition of the IMC phases and also the results of experimental points where only a liquid phase was observed. Figures 6 and 7 show the equilibrium results for the binaries and the discrepancies between these results and those of Hanson et al. ${ }^{[14]}$ Harding 


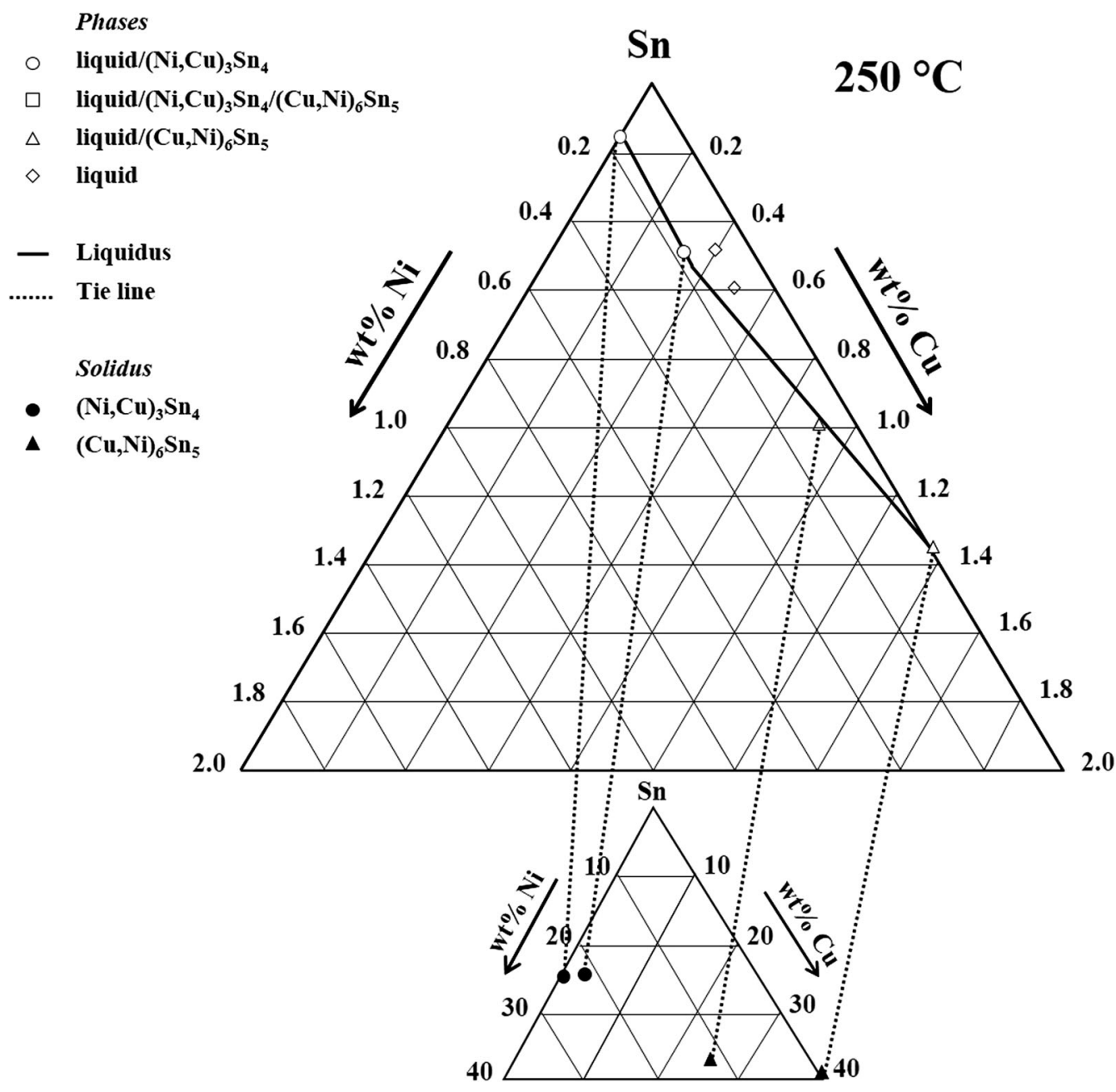

Fig. 11 -Equilibrium liquid/IMCs at $260^{\circ} \mathrm{C}$.

et al. ${ }^{[1]]}$ and the Thermo-calc. simulation for the system $\mathrm{Sn}-\mathrm{Cu}$. The differences of the results of the present work with those of Hanson et al. ${ }^{[14]}$ and the Thermo-calc. simulation for the $\mathrm{Sn}-\mathrm{Ni}$ system are also apparent.

A typical example of the observed coexistence of liquid/IMC is shown in Figure 8 and both the large size of the IMCs and the presence of two IMCs are apparent in Figure 8(c). The experimental results of liquidus lines for the ternaries are shown in Table VII. The isotherm at $240{ }^{\circ} \mathrm{C}, 250{ }^{\circ} \mathrm{C}, 260{ }^{\circ} \mathrm{C}, 270{ }^{\circ} \mathrm{C}$ is plotted in Figure 9 which includes the lines of separation between the primary phase fields of $(\mathrm{Ni}, \mathrm{Cu})_{3} \mathrm{Sn}_{4}$ and $(\mathrm{Cu}, \mathrm{Ni})_{6} \mathrm{Sn}_{5}$.
These lines were obtained by extrapolating of the tie lines for the equilibrium liquid $/(\mathrm{Ni}, \mathrm{Cu})_{3} \mathrm{Sn}_{4} /(\mathrm{Cu}, \mathrm{Ni})_{6} \mathrm{Sn}_{5}$ at the respective temperature.

The composition of the liquidus and the corresponding connection with the IMC are included in Figures 10 through 13 with projections at two different scales: one for the liquidus from 0 to $2 \mathrm{wt}$ pet of $\mathrm{Ni}$ and $\mathrm{Cu}$ in order to appreciate the details of the liquidus lines and another scale from 0 to $40 \mathrm{wt}$ pct of $\mathrm{Ni}$ and $\mathrm{Cu}$ to indicate the composition of the IMCs.

The compositions of the IMCs are summarized in Figure 14 in at. pct. At the experimental condition, the maximum solubilities of copper in $(\mathrm{Ni}, \mathrm{Cu})_{3} \mathrm{Sn}_{4}$ and nickel in $(\mathrm{Cu}, \mathrm{Ni})_{6} \mathrm{Sn}_{5}$ are around 8 at. pet $\mathrm{Cu}(4 \mathrm{wt}$ pct $)$ 


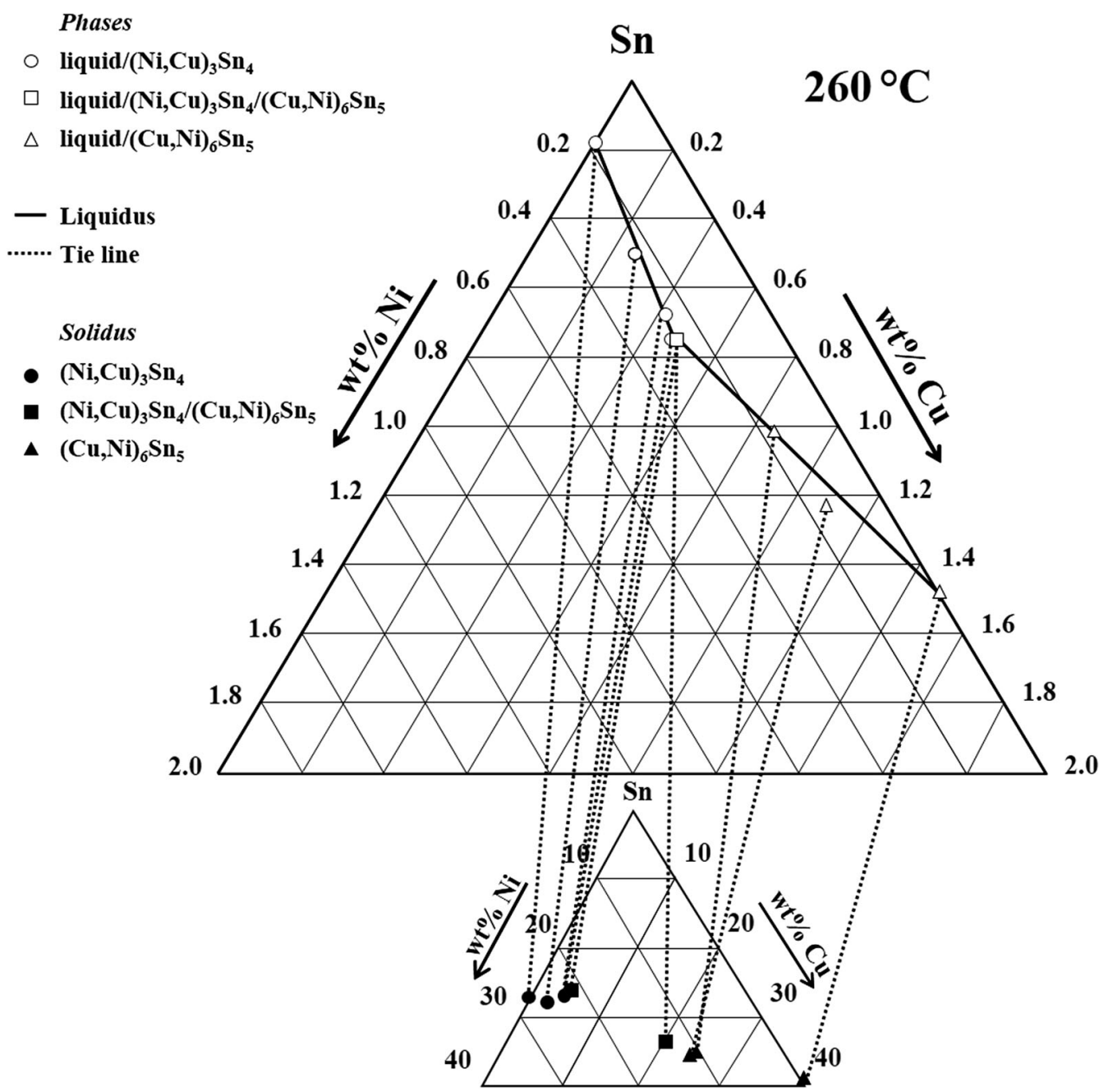

Fig. 12-Equilibrium liquid/IMCs at $270{ }^{\circ} \mathrm{C}$.

and 24 at. pct Ni (18 wt pct), respectively. These solubilities are in agreement with those reported by Schmetterer et al. ${ }^{[26]}$

The proposed ternary phase diagram is shown in Figure 15, including the liquidus lines reported by Vourinen et al.., ${ }^{[13]} \mathrm{Yu}$ et al., ${ }^{[12]}$ and Gourlay et al. ${ }^{[15]}$ The position of the invariant line was clearly determined. The eutectics of the $\mathrm{Sn}-\mathrm{Cu}$ and $\mathrm{Sn}-\mathrm{Ni}$ binaries were extrapolated from the present experimental work and in agreement with the reported temperatures included in Table I. It is clear that the discrepancies with previous experimental works and simulations were the liquidus lines; within the present work it has been extended till $0.31 \mathrm{wt}$ pct $\mathrm{Ni}$ at $270{ }^{\circ} \mathrm{C}$. The position of the invariant line is also substantially different from that suggested by Vourinen et al. ${ }^{[13]}$ and $\mathrm{Yu}$ et $a l .{ }^{[12]}$

\section{CONCLUSIONS}

The main objective of the present work was generating a new $\mathrm{Sn}-\mathrm{Cu}-\mathrm{Ni}$ phase diagram based on reliable experimental data. This objective required the improvement of reported methodologies to overcome the experimental shortcomings observed in the literature review. The developed equilibration methodology allowed the formation of large sized intermetallic 


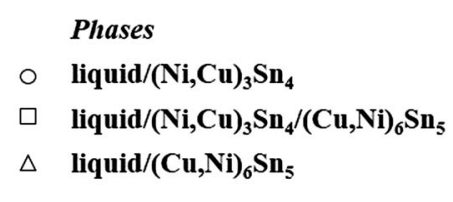
- Liquidus
....... Tie line
Solidus
- $(\mathrm{Ni}, \mathrm{Cu})_{3} \mathrm{Sn}_{4}$
- $(\mathrm{Ni}, \mathrm{Cu})_{3} \mathrm{Sn}_{4} /(\mathrm{Cu}, \mathrm{Ni})_{6} \mathrm{Sn}_{5}$
$\triangle(\mathrm{Cu}, \mathrm{Ni})_{6} \mathrm{Sn}_{5}$

\section{Sn}
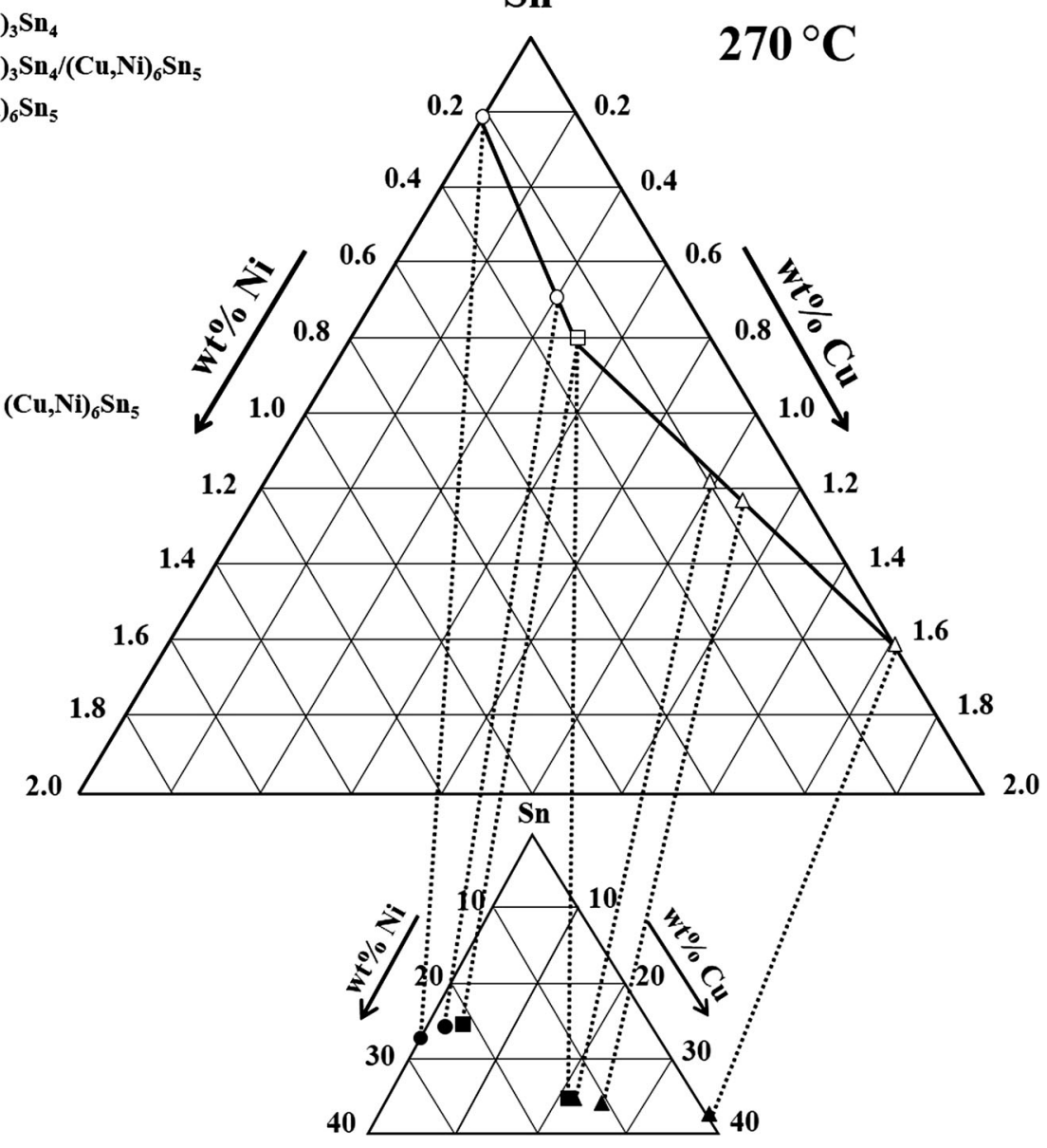

Fig. 13-Equilibrium liquid/IMCs at $280^{\circ} \mathrm{C}$.

compounds, a clear solid and liquid phase separation and the analysis of crystals in the bottom of the sample. A careful separation of the sample then allowed the associated phases of the liquid and solids to be elementally analyzed by ICP-AES and EPMA, respectively. In addition, the separation of phases was corroborated using electronic microscopy to observe the microstructure of solids formed in the bottom of the sample.
A consistent dataset of experimental data was obtained. The phase diagram included the liquidus lines at temperatures of $240{ }^{\circ} \mathrm{C}, 250{ }^{\circ} \mathrm{C}, 260{ }^{\circ} \mathrm{C}$, and $270{ }^{\circ} \mathrm{C}$, the invariant line of the diagram, and the tie lines of connections of the liquid phase with the intermetallic compounds. Furthermore, the phase diagram was also plotted along with the data reported in the literature. It is clear that there are considerably discrepancies with the work-previous experiments and simulations. 


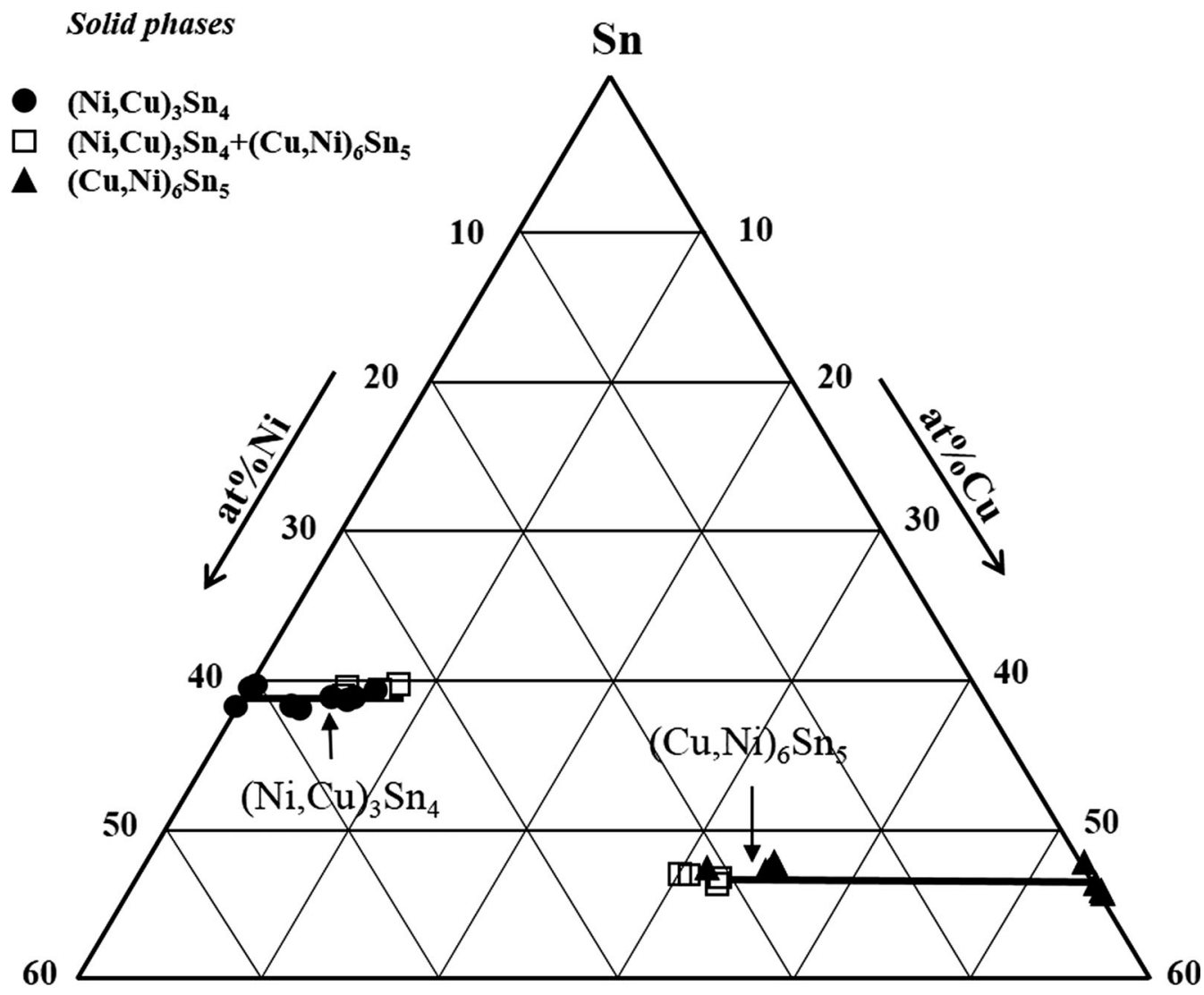

Fig. 14 Composition of IMC indicating the limit of solubility of $(\mathrm{Ni}, \mathrm{Cu})_{3} \mathrm{Sn}_{4}$ and $(\mathrm{Cu}, \mathrm{Ni})_{6} \mathrm{Sn}_{5}$.

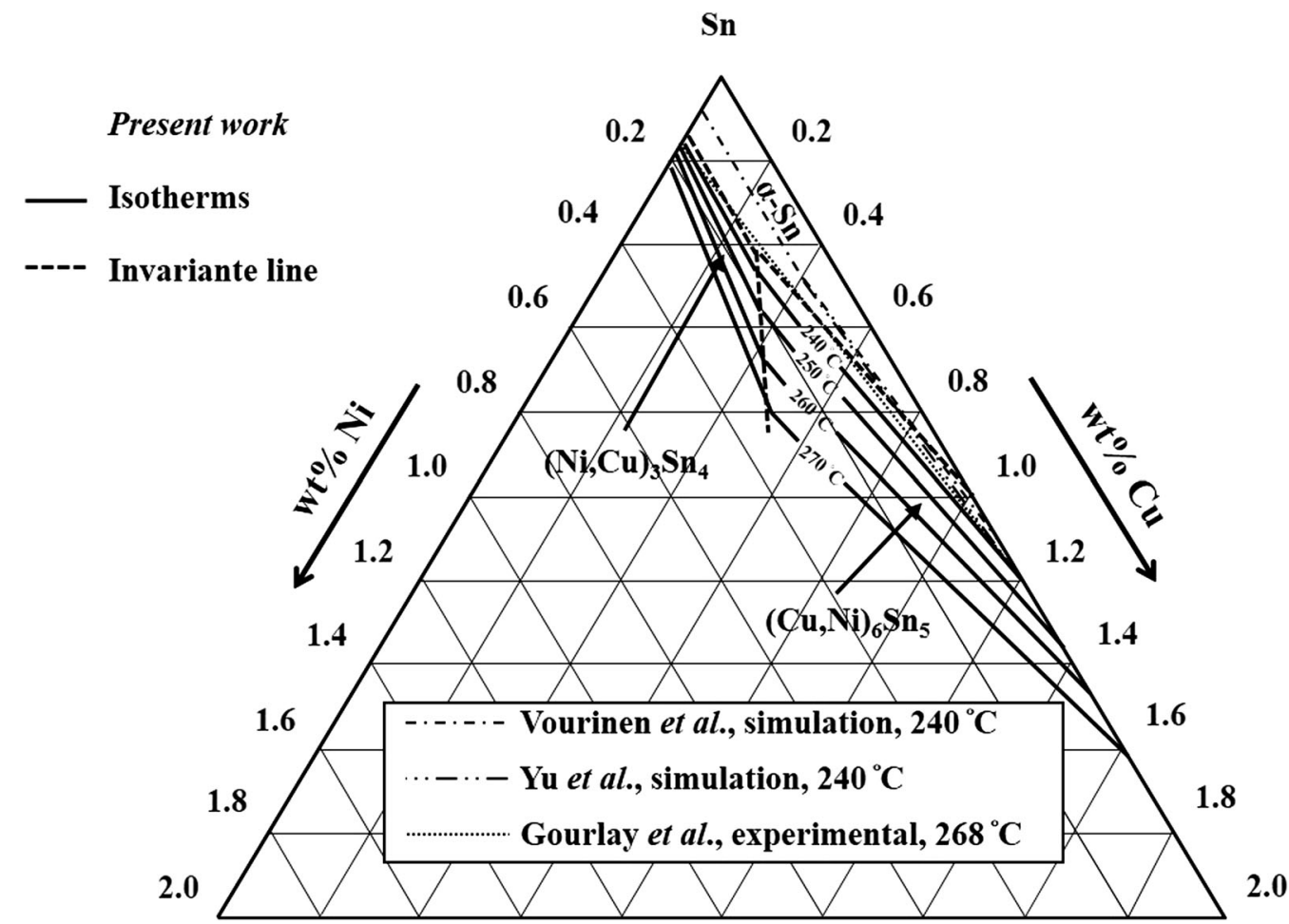

Fig. 15-Proposed phase diagram; the figure includes for comparison the liquidus lines proposed by Vourinen et al., Yu et al. and Gourlay et al. 


\section{OPEN ACCESS}

This article is distributed under the terms of the Creative Commons Attribution 4.0 International License (http://creativecommons.org/licenses/by/4.0/), which permits unrestricted use, distribution, and reproduction in any medium, provided you give appropriate credit to the original author(s) and the source, provide a link to the Creative Commons license, and indicate if changes were made.

\section{REFERENCES}

1. J.W. Evans and W. Engelmaier: A guide to lead-free solders: physical metallurgy and reliability, Springer, London, 2007, pp. 18.

2. K.N. Subramaniam: Materials reliability for electronics, Wiley Chichester, Chichester, 2012, pp. 233-50.

3. O.A. Ogunseitan: J. Met., 2007, vol. 59, pp. 12-17.

4. A. Kroupa, A.T. Dinsdale, A. Watson, J. Vrestal, J. Vízdal, and A. Zemanova: J. Met., 2007, vol. 59, pp. 20-25.

5. https://www.nist.gov/programs-projects/lead-free-solder.

6. A.T. Dinsdale, A. Watson, A. Kroupa, J. Vrestal, A. Zemanova, J. Vizdal: Atlas of phase diagrams for Pb-free soldering. 2008, Action number: 531, vol. 1, The European Science Foundation, and MTSOLDERS. v.1.0 database.

7. Thermo-calc. software tcsld3-2_extended_info http://www.thermo calc.com/media/19852/tcsld3-2_extended_info.pdf. Accessed 22 Oct 2017.

8. MTDATA-Phase Diagram Software from the National Physical Laboratory, SOLDERS: Database for lead free solders http://re source.npl.co.uk/mtdata/soldersdatabase.htm. Accessed 22 Oct 2017.

9. T. Laurila, V. Vuorinen, and M. Paulasto-Kröckel: Mater. Sci. Eng. $R, 2010$, vol. 68, pp. 1-38.
10. C.E. Ho, R.Y. Tsai, Y.L. Lin, and C.R. Kao: J. Electron. Mater., 2002, vol. 31, pp. 584-90.

11. J.V. Harding and W.T.P. Walpole: ASM Int., 1948, vol. 75, pp. 115-30.

12. H. Yu, V. Vuorinen, and J.K. Kivilahti: J. Electron. Mater., 2007, vol. 36, pp. 136-46.

13. V. Vuorinen, H. Yu, T. Laurila, and J. Kivilahti: J. Electron. Mater., 2008, vol. 37, pp. 792-805.

14. D. Hanson, E.J. Sandford, and H. Stevens: J. Inst. Met., 1934, vol. 55, pp. 115-33.

15. C.M. Gourlay, K. Nogita, J. Read, and A.K. Dahle: J. Electron. Mater., 2010, vol. 39, pp. 56-69.

16. H.S. Liu, J. Wang, and Z.P. Jin: Calphad, 2004, vol. 28, pp. 36370.

17. C. Schmetterer, H. Flandorfer, K.W. Richter, U. Saeed, M. Kauffman, P. Roussel, and H. Ipser: Intermetallics, 2007, vol. 15, pp. 869-84.

18. A. Zemanova, A. Kroupa, and A. Dinsdale: Monatshefte Für Chemie-Chemical Monthly, 2012, vol. 143, pp. 1255-61.

19. P. Nash and A. Nash: Bull. Alloy Phase Diagr., 1985, vol. 6, pp. $350-59$.

20. C.M. Gourlay, K. Nogita, S.D. McDonald, T. Nishimura, K. Sweatman, and A.K. Dahle: Scr. Mater., 2006, vol. 54, pp. 1557-62.

21. S.A. Belyakov and C.M. Gourlay: Intermetallics, 2012, vol. 25, pp. $48-59$.

22. G. Ghosh: Metall. Mater. Trans. A, 1999, vol. 30, pp. 1481-94.

23. C.R. Lin, S.W. Chen, and C.H. Wang: J. Electron. Mater., 2002, vol. 31, pp. 907-15.

24. L. Snugovsky, P. Snugovsky, D. Perovic, and J. Rutter: Mater. Sci. Technol., 2006, vol. 22, pp. 899-902.

25. S. Chen, C. Wang, S. Lin, and C. Chiu: J. Mater. Sci., 2007, vol. 18 , pp. 19-37.

26. C. Schmetterer, H. Flandorfer, C. Luef, A. Kodentsov, and H. Ipser: J. Electron. Mater., 2009, vol. 38, pp. 10-24.

27. D. $\mathrm{Mu}$ : Critical properties of $\mathrm{Cu}_{6} \mathrm{Sn}_{5}$ for high-temperature and $3 \mathrm{D}$ $\mathrm{Pb}$-free soldering applications, Ph.D. Thesis, The University of Queensland, Brisbane Australia, 2012.

28. Waidner \& Burgess: Bur. Stand. (U. S.), Bull., 1910, vol. 6, pp. 149-230. 